\title{
E-banking services impact and customer satisfaction in selected bank branches in Ibadan metropolis, Oyo state, Nigeria
}

\author{
Haadi Babatunde Asiyanbi ${ }^{a}$ and Ajibola Abdulrahamon Ishola ${ }^{*}$
}

${ }^{a}$ Bursary Department, Federal College of Education (Special), Oyo, Nigeria

${ }^{b}$ Department of Psychology, University of Ibadan, Ibadan, Nigeria

\begin{abstract}
A B S T R A C T
This study perused the impact of E-banking services on customer satisfaction of selected bank customers in bank branches located in Challenge, Dugbe, Agbeni, Gbagi, Ojoo, and Secretariat districts in Ibadan metropolis. The study employed a cross-sectional survey design and convenience sampling technique. One hundred (100) bank customers were surveyed through a self-report questionnaire. Four research questions and two hypotheses were tested using Pearson correlation analysis and, t-test for independence at $\mathrm{p} \leq 0.05$. The results revealed high utilization of electronic banking products (ATM $(98 \%)$, internet banking $(85 \%)$, electronic transfer $(97 \%)$. Constraints experienced include internet network failure, bank fraud and business loss due to failed e-transactions. Customers were satisfied with e-banking due to its cashless nature, cash accessibility, saves time from bank visitation and seamless transactions. The study exhibited that customers used and were glad with e-banking products. Customers' segmentation and more investment in e-banking infrastructure were advised for promoting electronic banking services.
\end{abstract}

\section{Introduction}

Electronic banking has occasioned an astounding growth in several countries particularly Africa and has remodelled the normal banking activities in Nigeria. Ovia (2005) conceptualise Electronic banking as providing services to customers via internet or mobile technology such as mobile phone, computers and Automated Teller machines (ATM), etc. These services enables financial institutional customers, people or businesses to access accounts, business transaction, or get data on monetary product through internet telecommunication networks (Prakash \& Malik, 2008). The Electronic Payment Methods (EPM) are simplified and personalized ways of conducting financial transactions (using mobile or internet) without involving physical cash or paper cheque reducing the instance where individuals have to carry large sums of cash and join lengthy queues on bank premises in order to conduct financial transaction (Jenevive \& Anyanwaokoro, 2017). E-banking offers speed, efficiency, comfort and security compared to physical banking procedures. Automated Teller Machine (ATM) and Point of

* Corresponding author

E-mail address: ajibola_ishola@yahoo.co.uk (A. A. Ishola) 
Sale (POS) have eliminated the need to use cheques and paper documentation (Jenevive \& Anyanwaokoro, 2017).

Electronic payment strategies have been adapted in Nigeria advancing by the increase in the share volume and worth of transactions accomplished through the ATM, POS, and Mobile phones, etc. For instance the volume of transactions executed with the ATM was put at N548.60 million in 2009 and this increased to N74.9 trillion in 2016 (Adegbesan, 2017). Thus, it is not doubtful concerning the penetration of electronic payment approaches in Nigeria (Jenevive \& Anyanwaokoro, 2017). In Nigeria major cities and financial hubs, E-banking services are increasingly gaining ground as the customers received them as panacea to the problems of poor quality services peculiar to the Nation's banking system. However, what is unknown is the level to which e-banking services have reduced the stress or problems associated with banking and enhanced customers' satisfaction (Taiwo \& Agwu, 2017). Emergent literature have identified that electronic banking in Nigeria is costly, occasioned by epileptic internet services, increase in the size of cash deposits, and increased exposure to fraudulent activities (Afolabi, 2009; Taiwo \& Agwu, 2017).

In the Ibadan metropolis, banking organizations are promoting electronic banking for use among its customers, however level of utilization seems low which was evidence with long queues at bank branches, low deployment of POS at supermarkets and most government and private organizations still prefer paying cash at revenue points evidenced in urban centers in Nigeria (Bello, 2005). Suggesting that the e-banking service is possibly ignored and underutilized despite its availability. It is in view of that the current study appraised the state of e-Banking adoption in the Ibadan metropolis and level of satisfaction with these products in the Ibadan metropolis. Specifically, this study seeks to:

- Identify the various electronic bank products presented/offered to bank customers in the metropolis.

- Describe the socio-economic characteristics of the responding bank customers.

- Appraise the consumer satisfaction with electronic services offered by banks.

- Evaluate the frequency at which branch visitation by customers have decline with adoption of e-banking services.

Two hypotheses stated that:

1. E-banking have not significantly enhanced customer satisfaction among bank customers in Ibadan.

2. The adoption of E-banking products and services has not caused a significant decline in bank visitation.

\section{Literature review}

This inquiry was anchored on the Disconfirmation theory by Oliver (1980) which postulates that consumer satisfaction with service or products is directly proportional to the magnitude and direction of the consumers' cognitive experience resulting from comparison of service performance and consumer expectations. Satisfaction is consumers' fulfilment response (Fang et al., 2010). In Nigeria, electronic banking products are gaining ground as customers received them as solution to the challenges of banking services delivery peculiar to Nigerian banks. E-banking have helped the banking organizations deliver more efficient services with less processing time, improved flexibility of transactions and reduction in overhead personnel costs (Adesina \& Ayo, 2010).

Appraisal of e-banking adoption and satisfaction with the services have shown that e-banking usage increased with the perception that it is convenient, very easy to use, reduce transaction time and flexible (Adesina \& Ayo, 2010). However, experts suggest that the rate at which Nigerians accept the products is far below expectation (Suleimon, 2007). 
Addai et al. (2015) survey study demonstrated a positive association between customer satisfaction and e-banking availability, reliability and convenience. Srivastav and Mittal (2016) investigated positive and negative variables influencing customers' satisfaction with Internet banking. They found that trust and service quality was associated with internet banking services and adoption. Ismail and Alawamleh (2017) found that e-banking adoption had a positive effect on Jordanian banks and customers' satisfaction rates. Firdous and Farooqi (2017) in an exploratory study found that dimensions of ebanking service quality was associated with consumer satisfaction.

\section{Methodology}

The inquiry was conducted within the Ibadan metropolis, Oyo state, Nigeria. The Primary data collected from cross-sectional field survey using questionnaires. The target population of the study comprised of banks customers sampled at the premises of bank branches located in the six business districts which include; Challenge, Dugbe, Agbeni, Gbagi, Ojoo and Secretariat Branches. These areas constitute the major business districts in the Ibadan metropolis. In this study, 100 customers were conveniently sampled from the customers visiting the selected branches.

\subsection{Instrument}

The questionnaire consisted of three parts. Part I tapped demographic information such as age, marital status, education attainment, etc. Part II sought information perceptions and disposition to electronic banking services. This was captured using items adapted from customers' satisfaction with E-Banking standardized instrument by Kumbhar (2011). The reliability was $\alpha=0.91$. The sub-dimensions of the scale include perceived value, brand perception and cost effectiveness; easy to use, convenience, problem handling, security/assurance and responsiveness, system availability, and fulfillment compensation. A cumulative customer's satisfaction index was estimated by summing the scores on all the items. High scores on the measure suggest high gratification and vice versa. Part III sought customer responses on frequency of visiting bank branches after embracing e-banking based on reason for visiting the bank. 4 items were scored on a Likert scale arrayed from $1=$ Not all, to $5=$ every day of the week. Reliability was 0.78 Cronbach alpha. The frequency of visit index was calculated by adding all the scores on the four items. Survey items on adoption, use of e-banking and service quality were responded to on a Likert scale arrayed from 1= "Strongly Disagree" to 5= "Strongly Agree" using items adapted from Kumbhar (2011). Reliability was 0.82 cronbach alpha. The section also contains items asking questions on perceived constraints to the use and adoption of e-banking products.

\subsection{Procedure}

Prior to the exercise of data collection, permission was sought and secured from the relevant authorities in the selected banks to conduct the study among its customers. In addition, research assistants were employed and trained in data collection techniques to enable them effectively seek audience from sampled customers.

\subsection{Method of data analysis}

The data was analysed using SPSS for windows version 20.0. The descriptive statistics include frequency counts and simple percentage. The Pearson correlation statistics were used to establish the co-variant relationship between the variables and t-test for independence used to examine differences between variables at $p \leq 0.05$ level of significance.

\section{Results}

Result revealed that more than half of the respondents were males below the age of 30 years, $29 \%$ were age between 31 to 40 years and $21 \%$ were $\leq 40$ years. $64 \%$ of the customers were married and 
$75 \%$ possessed First degree certificate, $15 \%$ had secondary school education and $10 \%$ were primary school certificate holders. $80 \%$ of the consumers had less than 5 dependents, $13 \%$ had 5-9 dependents and $7 \%$ had above 10 dependents. $55 \%$ of the consumers earned below $=\mathrm{N}=200,000,26 \%$ earn between $=\mathrm{N}=201,000-\mathrm{N}=500,000$ and $19 \%$ earned above $=\mathrm{N}=501,000$ monthly.

\section{Table 1}

Electronic banking utilization

\begin{tabular}{lcc}
\hline Item & Yes & No \\
\hline ATM & $99(99 \%)$ & $1(1 \%)$ \\
Internet banking & $85(85 \%)$ & $15(15 \%)$ \\
Bank transfer & $97(97 \%)$ & $3(3 \%)$ \\
E-money/purse & $14(14 \%)$ & $86(12 \%)$ \\
POS & $31(31 \%)$ & $69(69 \%)$ \\
Mobile money & $29(29 \%)$ & $71(71 \%)$ \\
\hline
\end{tabular}

Source: Authors computation

The larger percentage of the consumers reported using ATM, internet banking while only few reported the use of bank transfer, POS and mobile money and majority reported non-utilization of Emoney/purse.

\section{Table 2}

Perception of the quality of e-banking services offered by the service provider

\begin{tabular}{|c|c|c|c|c|c|}
\hline & SD & DA & $\mathrm{U}$ & A & SA \\
\hline $\begin{array}{l}\text { Electronic banking makes cash readily available whenever } \\
\text { you need it }\end{array}$ & $3(3 \%)$ & $15(15 \%)$ & $3(3 \%)$ & $50(50 \%)$ & $29(29 \%)$ \\
\hline Using electronic banking saves time from going to the bank & $3(3 \%)$ & $5(5 \%)$ & $6(2 \%)$ & $47(47 \%)$ & $44(44 \%)$ \\
\hline $\begin{array}{l}\text { Electronic banking services makes transaction easier and } \\
\text { safer }\end{array}$ & $5(5 \%)$ & $3(3 \%)$ & $4(4 \%)$ & $48(48 \%)$ & $41(41 \%)$ \\
\hline Electronic banking exposes one to internet fraud and credit & $10(10 \%)$ & $28(28 \%)$ & $10(10 \%)$ & $36(36 \%)$ & $16(16 \%)$ \\
\hline $\begin{array}{l}\text { Electronic banking helps me to save time from visiting } \\
\text { branch banks to conduct banking transactions }\end{array}$ & $4(4 \%)$ & $5(5 \%)$ & $3(3 \%)$ & $50(50 \%)$ & $38(38 \%)$ \\
\hline $\begin{array}{l}\text { Electronic banking allows me to conduct my business } 24 \\
\text { hours/day without waiting for banks opening hours }\end{array}$ & $7(7 \%)$ & $7(7 \%)$ & $3(3 \%)$ & $57(57 \%)$ & $27(27 \%)$ \\
\hline
\end{tabular}

$79 \%$ opined that electronic banking makes cash readily available whenever need arise. 83\% reported that electronic banking saves time from going to the bank, $90 \%$ viewed that electronic banking services makes transaction easier and safer. 52\%reported that electronic banking increases their vulnerability internet fraud and credit, $88 \%$ opined that electronic banking helps to save time from visiting branch banks to conduct banking transactions, 84\%) agreed that electronic banking allows the conduct of baking business 24 hours/day without waiting for banks opening hours.

\section{Table 3}

Impact of electronic banking on visitation to bank branches in the last six months after embracing ebanking products

\begin{tabular}{lllllll}
\hline Activities to carry out at the bank & No response & Not all & On demand $\begin{array}{l}\text { Once or } \\
\text { twice in a } \\
\text { month }\end{array}$ & $\begin{array}{l}3 \text { to } 4 \text { times } \\
\text { in a week }\end{array}$ & $\begin{array}{l}\text { Every day } \\
\text { of the week }\end{array}$ \\
\hline For banking transaction & $18(18 \%)$ & $9(9 \%)$ & $35(35 \%)$ & $30(30 \%)$ & $8(8 \%)$ & $1(1 \%)$ \\
For enquiry & $28(28 \%)$ & $9(9 \%)$ & $35(35 \%)$ & $22(22 \%)$ & $5(5 \%)$ & $1(1 \%)$ \\
To transfer money & $33(33 \%)$ & $11(11 \%)$ & $28(28 \%)$ & $25(25 \%)$ & $1(1 \%)$ & $4(4 \%)$ \\
To receive money & $17(17 \%)$ & $6(6 \%)$ & $38(38 \%)$ & $21(21 \%)$ & $14(14 \%)$ & $6(6 \%)$ \\
\hline Source: Authors computation & & & & & &
\end{tabular}


Table 3 shows that larger proportion $(35 \%)$ of the respondents reported that with introduction of electronic banking activities their visitation to the bank branches is now on demand, $30 \%$ now visits the bank branches once or twice in a month. Only, 35\% now visits the bank for enquiry when demanded compare to $22 \%$ who visit once or twice in a month. $28 \%$ presently visits the bank branches to transfer money on demand and $38 \%$ reported visiting the bank to receive money only when necessary to do so while $21 \%$ visit the bank once or twice in a month to receive money.

Table 4

Satisfaction with electronic banking

\begin{tabular}{|c|c|c|c|c|c|}
\hline Items & SD & DA & $\mathrm{U}$ & A & SA \\
\hline $\begin{array}{l}\text { I enjoy electronic banking which affords customers to } \\
\text { take less cash around }\end{array}$ & $2(2 \%)$ & $8(8 \%)$ & $3(3 \%)$ & $48(48 \%)$ & $40(40 \%)$ \\
\hline $\begin{array}{l}\text { I am completely satisfied with the services delivered by } \\
\text { my bank }\end{array}$ & $3(3 \%)$ & $16(16 \%)$ & $38(10 \%)$ & $45(45 \%)$ & $26(26 \%)$ \\
\hline $\begin{array}{l}\text { I feel very pleased with services offered through } \\
\text { electronic banking }\end{array}$ & $7(7 \%)$ & $15(15 \%)$ & $5(5 \%)$ & $46(46 \%)$ & $26(26 \%)$ \\
\hline I feel absolutely delighted with the electronic banking & $3(3 \%)$ & $11(11 \%)$ & $11(11 \%)$ & $52(52 \%)$ & $24(23 \%)$ \\
\hline $\begin{array}{l}\text { I would like to remain as a customer of my present bank } \\
\text { due to it electronic banking }\end{array}$ & $4(4 \%)$ & $13(13 \%)$ & $9(9 \%)$ & $47(47 \%)$ & $27(27 \%)$ \\
\hline I consider myself to be loyal to my bank and electronic & $3(3 \%)$ & $7(7 \%)$ & $8(8 \%)$ & $50(50 \%)$ & $33(33 \%)$ \\
\hline
\end{tabular}

Source: Authors computation

Significant number of the respondents agreed that they enjoy electronic banking, which affords customers to take less cash around, makes cash readily available whenever need arise. Majority were satisfied because electronic banking saves time from going to the bank, makes transaction easier.

Table 5

Constraints to the utilization of electronic banking

\begin{tabular}{|c|c|c|}
\hline Constraints & Yes & No \\
\hline Being stranded due to electronic banking problems & $56(56.1 \%)$ & $44(44 \%)$ \\
\hline experience credit card theft/online bank fraud & $14(14 \%)$ & $86(86 \%)$ \\
\hline $\begin{array}{l}\text { Business loss or challenges due to inability transact with heavy } \\
\text { cash due to bank restraints }\end{array}$ & $20(20 \%)$ & $80(80 \%)$ \\
\hline
\end{tabular}

Table 5; reveals that Constraints reported by a number of the respondents include being stranded due to electronic banking (56\%), credit card theft/online bank (14\%)and business loss or challenges due to inability to carry heavy transactions at the counter(20\%).

\subsection{Hypothesis testing}

$\mathrm{H}_{1}$ : E-banking have not significantly enhanced customer satisfaction among bank customers in Ibadan. The hypothesis was tested using Pearson $r$ correlational test and summary presented in Table 6.

\section{Table 6}

Pearson correlation test showing the relationship between e-product and services utilisation and Customer satisfaction

\begin{tabular}{lccccc}
\hline Variables & Mean & S.D & Df & r & P \\
\hline Customer satisfaction & 25.43 & 5.29 & 378 & \multirow{2}{*}{$* 36^{* *}$} & $<.01$ \\
Utilization of electronic banking products and services & 7.59 & 2.08 & 378 & & \\
\hline
\end{tabular}

**Pearson correlation significant 0.01 level of significance (2 -tailed) 
The results obtained from the test are shown in Table 5 shows that utilization of e-banking products, services was a positive co-variant of customer satisfaction $(\mathrm{r}=.36, \mathrm{p}<.01)$ indicating that in electronic banking products, services significantly relate to increase in satisfaction. The null hypothesis not accepted and the working hypothesis is supported.

$\mathrm{H}_{2}$ : The adoption of E-banking products and services has not caused a significant decline in bank visitation. The hypothesis was tested using t-test for independence statistics and summary presented in Table 7:

\section{Table 7}

t-test summary table showing the influence of electronic banking utilisation on Frequency of bank visitation

\begin{tabular}{llrrrrrr}
\hline & $\begin{array}{l}\text { Level of electronic } \\
\text { banking utilization }\end{array}$ & N & Mean & S.D & df & t & P \\
\cline { 2 - 8 } $\begin{array}{l}\text { Frequency of } \\
\text { Bank visitation }\end{array}$ & Low utilization & 104 & 8.85 & 5.44 & & & \\
\hline
\end{tabular}

Results in Table 7, reveals that low utilization of e-banking products $(\mathrm{M}=8.85, \mathrm{~S} . \mathrm{D}=5.44)$ significantly occasioned reported lower averaged frequency of bank visitation compared to high utilization of electronic banking products $(M=4.93, S . D=3.65)$. The result indicates that utilization of electronic banking services reduced the constancy of bank visitation $(\mathrm{t}(98)=3.37, p<.01)$. This demonstrates that high utilization of e-banking products reduced frequency of bank visitation among the present sample. The null hypothesis is not accepted and the working hypothesis is supported.

\section{Discussion}

From the results, this study has empirically demonstrated that there was a high utilization of electronic banking products. ATM, internet banking and electronic transfer are the commonly utilized e-banking products. This is consistent with findings from Bello (2005), Taiwo and Agwu, (2017), Adesina and Ayo (2010). It was confirmed that internet network failure, bank fraud and business loss due failed etransactions were the common constraints reported by the customers. This is also consistent with Taiwo and Agwu (2017), Adesina and Ayo (2010). The findings showed that there was a significant decline in bank visitation which disagrees with earlier findings by Bello (2005). This finding however agrees with the work of Worku et al. (2016) who found a significant decline due to the adoption of e-banking products.

Customers were satisfied with e-banking with emphasis on its cashless nature, cash accessibility, saves time from bank visitation and seamless transactions. This is in agreement with Firdous and Farooqi (2017) who found association between dimensions of e-banking service quality and consumer satisfaction. The study also demonstrated that E-banking utilization was associated with customer satisfaction. This is in agreement with findings of Addai et al. (2015), Srivastav and Mittal, (2016); Ismail and Alawamleh (2017) who demonstrated that e-banking services was associated with increased customers satisfaction with banking services.

\section{Conclusion and Recommendation}

This inquiry has demonstrated that the patronage of e-banking products is on the increase and bank clients are satisfied with e-banking experience. The banking organisations were advised to increase awareness about electronic banking system through sensitizing its customers, particularly the nonadopters, about the various gains associated with e-banking so as to encourage its adoption. To further reduce the challenges associated with users interface, graphical presentation and pictorials should be on display at bank's branches. The banking organizations should endeavor to minimize the costs 
associated with e-banking. They should not introduce fees for similar banking services that are free-ofcharge in the physical world (for example, at bank branches and/or ATMs). For further studies, it was advised that researchers interested in future inquiry can extended the research to corporate customers, and comparison could then be made between private and corporate customers to include factors influencing decisions to embrace, select e-banking and services perceived to be useful. In addition, the sample size should be increased in a study of the whole banking sector.

\section{Acknowledgement}

We declared that there is no conflict of interest, this study was entirely self-sponsored and informed consent obtained from the respondents.

\section{References}

Addai, O., Ameyaw,B., Ashalley, E., \& Quaye, I.(2015) Electronic Banking and Customer Satisfaction: Empirical Evidence from Ghana. British Journal of Economics, Management \& Trade, 9(3), 1-8. DOI : 10.9734/BJEMT/2015/19269.

Adegbesan, E. (2017, November 3) E-payment transactions up 33\% to N74.9trn in 2016 CBN.Vanguard Newspaper. Retrieved 27/1/2018 from https://www.vanguardngr.com/2017/11/epayment-transactions-33-n74-9trn-2016-cbn/

Adesina, A. A. \& Ayo, C.K. ( 2010) An empirical investigation of the level of users' acceptance of ebanking adoption: A study of E-Commerce adoption. Journal of Association. Information System, $1,1-28$.

Afolabi, F. O. (2009). The role of information technology in Nigeria Banks: A case study of Intercontinental bank. Guaranty Trust Bank and First bank PLC, p. 10.

Bello, D. A. (2005). The impact of E-banking on customer satisfaction in Nigeria. University Library of Munich, Germany.

Fang, V. W., Tian, X., \& Tice, S. (2014). Does stock liquidity enhance or impede firm innovation?. The Journal of Finance, 69(5), 2085-2125.

Firdous, S., \& Farooqi, R. (2017). Impact of Internet Banking Service Quality on Customer Satisfaction. The Journal of Internet Banking and Commerce, 22(1), 1-17.

Ismail, L. B., \& Alawamleh, M. (2017). The Impact of Online Banking of Customer Satisfaction in Jordan. JOURNAL OF ORGANISATIONAL STUDIES AND INNOVATION, 4(2), 1-13.

Jenevive, O. C., \& Anyanwaokoro, M. (2017). Electronic Payment Methods and Profitability of Banking Firms in Nigeria: A Panel Data Analysis. International Journal of Finance and Accounting, 6(3), 67-74.

Kumbhar, V. M. (2011). Factors affecting the customer satisfaction in e-banking: Some evidences form Indian banks. Management Research \& Practice, 3(4), 1-14.

Oliver, R. L. (1980). Theoretical bases of consumer satisfaction research: Review, critique, and future direction. Theoretical developments in marketing, 206-210.

Ovia, J. (2005). Enhancing the efficiency of the payment system in Nigeria. CBN Bullion, 29(1), 8-18.

Prakash, A., \& Malik, G. (2008). Empirical Study of Internet Banking in India. Internet Research, 12(5), 83-92.

Srivastav, G., \& Mittal, A. (2016). Impact of Internet banking on customer satisfaction in private and public sector banks. Indian Journal of Marketing, 46(2), 36-49.

Suleiman, B. (2007). Report on the Survey of Developments in the e- payments and Service Products of Banking and other Financial Institutions in Nigeria. Central Bank of Nigeria Library, P.A 6- 14.

Taiwo, J. N., \& Agwu, M. E. (2017). The role of e-banking on operational efficiency of banks in Nigeria. Basic Research Journal of Business Management and Accounts, 6(1), 01-10.

Worku, G., Tilahun, A, \& Tafa, M.A. (2016). The Impact of Electronic Banking on Customers' Satisfaction in Ethiopian Banking Industry (The Case of Customers of Dashen and Wogagen Banks 
in Gondar City). Journal of Business and Financial Affairs, 5, 174. doi:10.4172/21670234.1000174

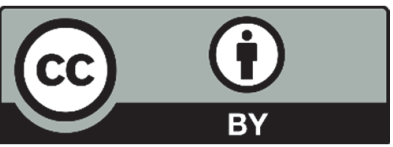

(C) 2018 by the authors; licensee Growing Science, Canada. This is an open access article distributed under the terms and conditions of the Creative Commons Attribution (CC-BY) license (http://creativecommons.org/licenses/by/4.0/). 